Journal of University of Babylon for Engineering Sciences, Vol. (26), No. (7): 2018.

\title{
Numerical Investigation of Influence of Multi-Line Fuel Injection (Methane) on a Tubular Combustor Emissions of Micro Gas Turbine
}

\author{
Arkan Khikhal Husain \\ Mechanical Engineering Department University of Technology, Baghdad, Iraq \\ arkanltaie@yahoo.com \\ Mahmood Attallah Mashkoor \\ Mechanical Engineering Department University of Technology, Baghdad, Iraq \\ MahmoodMashkoor@hotmail.com \\ Fuad Abdul Ameer Khalaf \\ Mechanical Engineering Department University of Technology, Baghdad, Iraq \\ me.21325@uotechnology.edu.iq
}

Submission date:- 2/4/2018

Acceptance date:- 3/5/2018

Publication date:- 18/7/2018

\begin{abstract}
This work presents a technique for design optimization of a gas turbine tubular combustor. This technique is based on the use of computational fluid dynamics (CFD) with CFX solver to reduce emission gases by using multi-line of fuel injection in secondary zone. This research relates the mass fraction of the multi-line of fuel injection as well as the equivalence ratio of the tubular combustion chamber designed for methane fuel. By using k- $\varepsilon$ as turbulent model and Probability Density Function (PDF) Flamelet as combustion model. The operating casing data of micro size gas turbine are used, the validation of fuel flow mixing and combustion analyses were carried out with a focus on species concentration in the combustor outlet section. With variant fuel mass flow rate fraction in fuel lines $\left(\mathrm{F}_{2} / \mathrm{F}_{1}\right)$, It was found that, with the new design $\mathrm{NO}$ reduced about $56 \%$ for the mass fraction 3 in high equivalence ratio and about 30\% for the mass fraction 1 for a low equivalence ratio, while reduction in outlet temperature profile (pattern factor) is about $45 \% \rightarrow 35 \%$.
\end{abstract}

Key words: Gas Turbine, Tubular Combustor, Low Emission, Methane Fuel.

Journal of University of Babylon for Engineering Sciences by University of Babylon is licensed under a Creative Commons Attribution 4.0 International License. 


\section{Nomenclature}
A
Area $\left[\mathrm{m}^{2}\right]$.
D Diameter [m].
$\mathrm{F}_{1} \quad$ Fuel Mass Flow Rate in main Injection Line.
$\mathrm{F}_{2} \quad$ Fuel Mass Flow Rate in Secondary Injection Line.
$\mathrm{F}_{\mathrm{t}} \quad$ Total Fuel Injected in to Combustor.
L Length $[\mathrm{m}]$.
$\mathrm{m}^{\bullet} \quad$ Flow Rate $[\mathrm{kg} / \mathrm{s}]$.
M.L.F.I main line of fuel injection.
NO Nitric Oxide.
$\mathrm{N}_{\mathrm{h}} \quad$ Number of Holes.
$P \quad$ Total Pressure $[\mathrm{Pa}]$.
$\begin{array}{ll}P_{r} & \text { Pressure Ratio }(P 3 / P 1) .\end{array}$
qRef Dynamic pressure along the combustor.
S.L.F.I secondary line of fuel injection.
$\mathrm{T} \quad$ Total Temperature [K].
V Velocity [m/s].

\section{Greek Symbols}

$\Phi \quad$ Equivalence Ratio.

$\theta \quad$ Angle (Diffuser or Snout or Dome) [ $\left.{ }^{\circ}\right]$.

Bsw $\quad$ Swirler Blade Stagger Angle (Flat Blade) [ $\left.{ }^{\circ}\right]$.

\section{Subscripts}

1

3

4

$\mathrm{f}$

RZ

PZ

$\mathrm{SZ}$

DZ

diff

SW

diff

$\mathrm{h}$
At Compressor Inlet.

At Chamber outlet.

At Chamber Outlet.

Fuel.

Recirculation Zone.

Primary Zone.

Secondary Zone.

Dilution Zone.

Diffuser.

Swirler.

Diffuser.

Hole. 
Journal of University of Babylon for Engineering Sciences, Vol. (26), No. (7): 2018.

\section{Introduction:}

The design and development of the combustion system of gas turbine require a more thorough understanding of the flow within the combustor and important processes of fuel injection and combustion J. W. Saywers[1]. In a gas turbine, the combustor is (adding energy to the system to power the turbines, and produce (high velocity gas to exhaust (through the nozzle in aircraft applications. Combustion chambers must be designed to ensure stable combustion of the fuel injected and (optimum fuel utilization within the limited space available and over a large range of air/fuel ratios. H. Cohen[2]. A typical numerical gas turbine combustor design (optimization and (development approach based on extensive use of the experience data based on a correlation has been fairly (effective. Distributed fuel (injection combustion is promising technology that (decreases of pollutants and improve combustion efficiency. The review in this section presents previous studies on Mild combustion and gas turbine combustor design. NO Abatement Research shows the reduction of $\mathrm{NO}$ emissions depend on the dispersed of the hot spot and elimination of the maximal temperature generated inside the combustion chamber [3]. G. B. Hornyák et. al. [4], studied numerically the difference between the combustion models in CFD mode as Numerical Modelling and Validation of the Combustion in a Gas Turbine and identified the characteristic of each models concluded, The Eddy Dissipation Model (EDM) is especially suitable for the chemical reactions, which go through in a short time, and the fluid flow is turbulent and non-premixed. In EDM the regress of elementary reaction $\mathrm{k}$, is determined by the smallest of the reactants limiter and products limiter The PDF Flamelet Model (PFM) can be used, if the flame is turbulent, the Damköhler number is much greater than 1 and non-premixed. Chemical reactions not influence the mixture fraction, because it deals with elements rather than molecules, and elements are not affected by chemistry. Ansys Fluent Non-Premixed model can be used for fast, turbulent reactions, in the case of chemical equilibrium, or laminar flamelet structure. With these certain assumptions, the Thermochemistry can be reduced to a single parameter. F.Pathan et. al. [5], studied numerically the combustion of methane-air mixture in gas turbine can-type combustion chamber. The goal is to recognize the combustion phenomena and (resulted emissions. (With the high cycle (temperature of modern gas turbine, mechanical (design remains difficult and a mechanical development (program is inevitable. The (rapidly increasing (use of computational fluid (dynamics (CFD) in recent years has had a major impact on the design process, greatly increasing the understanding of the complex (flow and so reducing the (amount of trial (and error (required. The gas turbine (can-combustor is (designed to burn the fuel (efficiently, reduce the emissions, and lower the wall temperature. In this study, various parameters like air-fuel ratio, swirler (angle of primary air inlet, axial position of (dilution holes are changed to investigate the effect of these parameters on combustion chamber performance and emissions. In this (study, the mathematical models used for (combustion consist of the PDF flamelet model and eddy dissipation combustion model for nonpremixed gas combustion. The outcome of the work (will help in finding out the (geometry of the combustion chamber (which will lead to less emission. F. Luis Goular Dias, et. al. [6],studied numerically the effects of reference area of $600 \mathrm{~kW}$ gas turbine tubular combustor on the burning, using shear stress transfer model for turbulence flow field simulation by ANSYS CFX and PDF flamelet as combustion model with mixture of 
Journal of University of Babylon for Engineering Sciences, Vol. (26), No. (7): 2018.

combination gaseous fuel and $4.288 \mathrm{~kg} / \mathrm{s}$ air mass flow rate concluded as increasing in reference area caused reduction in burning rate with enhanced combustion process also the reduction of air velocity at the swirle region has develop the dispersal of flame along the combustor. L. Wang, et. al. [7], studied numerically the Influence of Re on MILD Combustion of Gas Turbine, concluded Air jet Reynolds number has an important effect on the high temperature flue gas recycling rate $\mathrm{Kv}$ and Moderate or Intense Low oxygen Dilution (MILD) combustion mode is formed when $\mathrm{Kv}$ larger than 3. The formed MILD combustion has characteristics of space reaction, high combustion efficient, very low NOx and CO emissions, and good equality temperature field of outlet section.

S. Kumaresh, et. al. [8], studied numerically combustion and emission characteristics in a can-type combustion chamber. The tubular-combustor is designed to burn gases fuel (methane) efficiently to reduce the emissions, and drop the wall temperature. Various parameters like air-fuel ratio, swirler angle of primary air inlet, axial position of dilution holes are changed to investigate the effect of these parameters on combustion chamber performance and emissions. The modeling employs nonorthogonal curvilinear coordinates, second order accurate discretization, tetra grid iterative solution procedure and SST turbulence model. The mathematical models used for combustion consist of the PDF flamelet model and eddy dissipation combustion model for non-premixed gas combustion. The requirement of excess air is necessary to assure the oxidation of hydrocarbon molecules. Using $10 \%$ of excess air. Concluded to obtain effective combustor with less NOx emission. Numerical investigation on Can-type combustion chamber shows that $60^{\circ}$ swirler geometry is givin less NO emission as the temperature at the exit of combustion chamber is less as compared to $30^{\circ}$ and $45^{\circ}$ swirler angle geometry. So that for further numerical analysis $60^{\circ}$ geometry is used. The results from the parametric studies indicate that the calculation of NOx emission serves to develop low emission combustor. Thus, it can be noted that the use of 60 degree axial swirler angle at the secondary inlet location of $200 \mathrm{~mm}$ achieves low emission and to prevail better performance in aerospace applications. E. Oliveira, et.al. [9], studied numerically the effects of the Position of injected air holes in Primary and Secondary Zones on the exit temperature profile (pattern factor) on can combustor of Gas Turbine for Ethanol fuel, using the FLUENT package with SST adopted model for turbulent flow and Non-Premixed Combustion PDF flamlet model foe combustion processes, Were varied air injection holes positions of the primary and secondary zone and fixed the location of the dilution zone holes. For this purpose each zone primary and secondary lengths are divided into four sub length: $25 \%, 50 \%, 75 \%$ and $100 \%$ of their original length dimensions. Concluded that the positioning of the Primary zone holes has a great influence on the pattern factor than the positioning of Secondary zone holes, pattern factor shows high sensitive to rows of primary holes displacements. For the Primary zone holes, a reasonable explanation is based on the fact that there is a strong revers flow zone in the first three quarters of the Primary zone length. This condition is observed when positioning the Primary zone holes row in downstream these 0.75 of the primary zone length, in other words, thereby reducing the demand on the downstream zones in obtaining lower pattern factor. 
Journal of University of Babylon for Engineering Sciences, Vol. (26), No. (7): 2018.

Developed design methodologies would be useful for researchers for preliminary design assessments of a gas turbine combustor. In this study, step by step preliminary design methodologies of tubular combustor have been used.

The effect of the multi-line of fuel injection in the secondary zone has also been studied numerically; the overall contribution to knowledge of this study is development of combustor fuel injection methodologies with different variants.

\section{Combustor Preliminary design calculations.}

preliminary design of the Gas Turbine Combustor Design (GTCD) combustor depend on a computational tool developed by J. Saywers [1] and H. Lefebvre [3] and implemented in mathcad15. The GTCD enables the design of combustors fueled by Methane fuel, provided that changed the thermochemical parameters of temperature increase as a function of equivalence ratio for fuel adopted. Such a design methodology, in which GTCD is based, considers for the design of combustors, two criteria that must be met in all conditions of the operating envelope of the combustor: aerodynamic and thermochemical. Obtained for both criteria the reference area of the casing cross section $\left(A_{r e f}\right)$, corresponding to the combustor in study. It is adopted in designing the reference area that meets both criteria above. Defined $A_{\text {ref }}$, obtained the following calculations performed by the tool, the main ones being:

- Diameter of the liner $\left(D_{L}\right)$.

- Longitudinal lengths of the primary zone $\left(L_{P z}\right)$, secondary zone $\left(L_{S z}\right)$ and dilution zone $\left(L_{D z}\right)$.

- Dimensions of the diffuser $\left(L_{D i f f}\right)$ and swirler diameter $\left(D_{S w}\right)$.

- Diameter of primary zone holes $\left(D_{P h}\right)$, secondary zone hols $\left(D_{S h}\right)$ and dilution zone holes $\left(D_{D h}\right)$.

For the aerodynamic criterion if the combustor is dimensioned for a certain pressure loss, it will be large enough to accommodate the chemical reaction, J. Saywers [2]. The mixing process of fuel and air is extremely important. A good mix in the primary zone is essential for high burning rate and to minimize UHC and soot formation, H. Lefever [3] and S. Cohen [1]. A satisfactory mixture air-fuel inside the flame tube, and a relatively steady flow throughout the chamber, are aimed at the design of combustor, leading consequently to shorter combustors and lower pressure losses.

By the aerodynamic criterion, preliminary casing and flame tube diameters are estimated using equations (1) and (2).

$$
\begin{aligned}
& A_{\text {ref }}=\left[\frac{R_{\text {air }}}{2} \cdot\left[\frac{m_{3 \cdot} \sqrt{T_{3}}}{p_{3}}\right]^{2} \cdot\left[\frac{\frac{\Delta p_{3-4}}{q_{\text {ref }}}}{\frac{\Delta p_{3-4}}{p_{3}}}\right]\right]^{0.5} \\
& \frac{A_{\text {lin }}}{A_{\text {ref }}}=0.65
\end{aligned}
$$


Journal of University of Babylon for Engineering Sciences, Vol. (26), No. (7): 2018.

The aerodynamic phenomena play a vital role in the design and performance of the gas turbine combustion. As already mentioned, generally, if the aerodynamic design is satisfactory and the fuel injection system is suitable for the combustor, so do not expect operational problems. Using Mathcad package for programing the above equations 1 and 2 for the combustor inlet boundary conditions in table 1 to get the final preliminary design results in table 2

Table: 1, inlet boundary condition

\begin{tabular}{|c|c|c|}
\hline Variable & Value & Unite \\
\hline $\boldsymbol{m}_{\mathbf{3}}$ & 0.6 & $\mathrm{Kg} / \mathrm{s}$ \\
$\boldsymbol{m}_{\boldsymbol{f}}$ & 0.0166 & $\mathrm{Kg} / \mathrm{s}$ \\
\hline $\boldsymbol{P}_{\mathbf{3}}$ & $1.5 E 5$ & $\mathrm{pa}$ \\
\hline $\boldsymbol{P}_{\text {ratio }}$ & 1.4 & - \\
\hline $\boldsymbol{T}_{\mathbf{3}}$ & 600 & $\mathrm{~K}$ \\
\hline $\boldsymbol{V}_{\mathbf{3}}$ & 50 & $\mathrm{~m} / \mathrm{s}$ \\
\hline
\end{tabular}

Table: 2, preliminary design results.

\begin{tabular}{|c|c|c|}
\hline Variable & Value & Unite \\
\hline $\boldsymbol{A}_{\text {ref }}$ & 0.0346 & $m^{2}$ \\
\hline $\boldsymbol{A}_{\text {lin }}$ & 0.0224 & $m^{2}$ \\
\hline $\boldsymbol{A}_{\boldsymbol{s} \boldsymbol{w}}$ & $8.329 e-4$ & $m^{2}$ \\
\hline $\boldsymbol{D}_{\boldsymbol{r e f}}$ & 0.21 & $m$ \\
\hline $\boldsymbol{D}_{\text {lin }}$ & 0.17 & $m$ \\
\hline $\boldsymbol{D}_{\boldsymbol{s} \boldsymbol{w}}$ & 0.048 & $m$ \\
\hline $\boldsymbol{D}_{\boldsymbol{s} \boldsymbol{w} \boldsymbol{h u b}}$ & 0.025 & $m$ \\
\hline $\boldsymbol{L}_{\boldsymbol{p} z}$ & 0.1269 & $m$ \\
\hline $\boldsymbol{L}_{\boldsymbol{s z}}$ & 0.0846 & $m$ \\
\hline $\boldsymbol{L}_{\boldsymbol{d} z}$ & 0.225 & $m$ \\
\hline $\boldsymbol{L}_{\boldsymbol{D i f f}}$ & 0.038 & $m$ \\
\hline $\boldsymbol{L}_{\boldsymbol{D o m}}$ & 0.0223 & $m$ \\
\hline $\boldsymbol{D}_{\boldsymbol{p h}}$ & 0.022 & $m$ \\
\hline $\boldsymbol{D}_{\boldsymbol{s h}}$ & 0.014 & $m$ \\
\hline $\boldsymbol{D}_{\boldsymbol{D h}}$ & 0.032 & $m$ \\
\hline $\boldsymbol{\theta}_{\text {Dom }}$ & 69.86 & $\boldsymbol{o}$ \\
\hline $\boldsymbol{\theta}_{\text {Diff }}$ & 26.3 & $\boldsymbol{o}$ \\
\hline
\end{tabular}

\section{Combustor Geometry:}

In this section, the final dimensions results of preliminary design in table 3 have drawn as geometry through employing AutoCAD 2016. However, the geometry that utilized in the experimental study as shown in Figure (1).

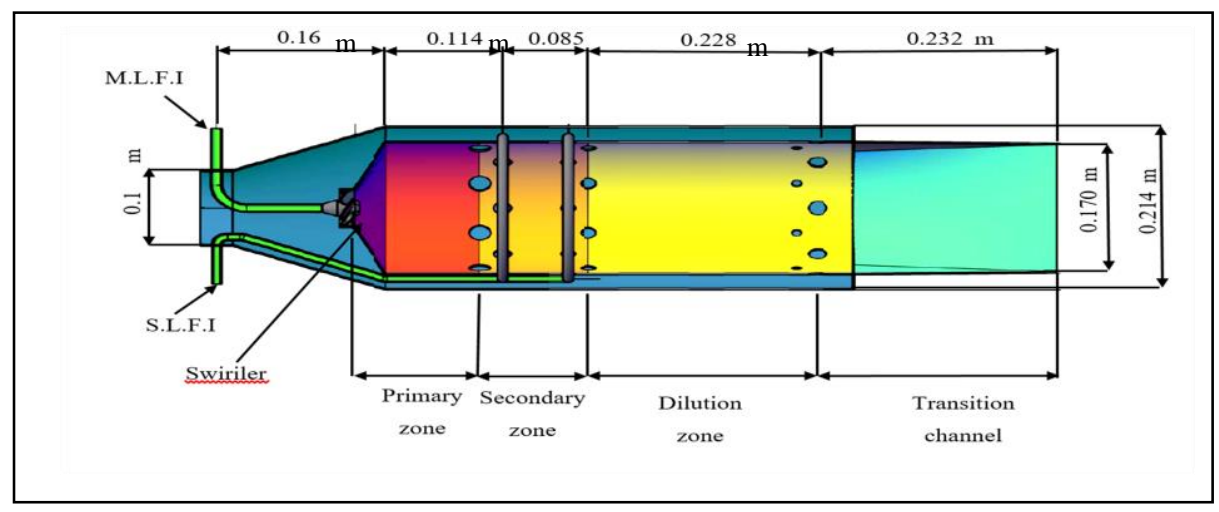

Figure: 1, combustor detail 
Journal of University of Babylon for Engineering Sciences, Vol. (26), No. (7): 2018.

\section{CFD Optimization:}

This section presents the numerical part of this work to analyze and simulate the case of optimization of volumetric reactant fluid flow and associated phenomena are considered as one of the involved matters in the system analysis that depends on the several fields of science. In this work, the three-dimensional model for the combustion model system will be simulated numerically by ANSYS CFX 17.2 package. Assessment of the flow feature by using k- $\varepsilon$ as turbulent model and PDF Flamelet as combustion model. In order to analyze the flow field inside gas turbine tubular combustor, governing equations will be used in this study, which are continuity, momentum, energy and species chemical equations are:

$$
\begin{array}{lr}
\frac{\partial}{\partial x_{j}}\left(\rho u_{j}\right)=0 & \text { Continuity equation } \\
\frac{\partial}{\partial x_{j}}\left(\rho u_{i} u_{j}\right)=-\frac{\partial p}{\partial x_{i}}+\frac{\partial}{\partial x_{j}}\left[\mu_{e f f}\left[\frac{\partial u_{i}}{\partial x_{j}}+\frac{\partial u_{j}}{\partial x_{i}}\right]\right] & \text { Momentum equation } \\
\frac{\partial}{\partial x_{j}}\left(\rho u_{i} h\right)=-\frac{\partial p}{\partial x_{i}}+\frac{\partial}{\partial x_{j}}\left[\frac{\mu_{e f f}}{P r_{T}} \frac{\partial h}{\partial x_{i}}\right]+H_{v} x \dot{\omega}_{f}-\nabla \cdot q^{R} & \text { Energy equation } \\
\frac{\partial}{\partial x_{j}}\left(\rho u_{j} Y_{i}\right)=-\frac{\partial p}{\partial x_{i}}+\frac{\partial}{\partial x_{j}}\left[\frac{\mu_{e f f}}{S c_{T}} \frac{\partial Y_{i}}{\partial x_{i}}\right]+\dot{\omega}_{l} &
\end{array}
$$

The com putational fluid domain discretization (numerical mesh generation) software was realized in Meshing, the same package of scientific software (ANSYS, CFX Workbench 17.2). The secondary line of fuel injection domain encompasses one swirler and each row of holes area which extracted from the main hole area of the primary and secondary holes area and fuel injection of the secondary combustion zone has eight holes in each row while in the primary there is eight holes with $18 \mathrm{~mm}$ in diameter bound to the first injection eight holes with $14 \mathrm{~mm}$ in diameter, and secondary zone holes with eight holes of $14 \mathrm{~mm}$ diameter bound the second row of injection holes of $12 \mathrm{~mm}$ in diameter as shown in Figure: 2, Considering the fact that equivalence tubular combustor is designed to have swirler with 6 straight vanes with angle of inclination of $60^{\circ} \mathrm{E}$. Oliveira [10], which provided swirler number of 1.3 J. Saywers[1] and H. Lefebver [3]. These regions are totaling approximately 5 million of cells. Mesh independence tests showed that this degree of refinement in the discretization is satisfactory to ensure the quality of the results as shown in figure: 3 . 
Journal of University of Babylon for Engineering Sciences, Vol. (26), No. (7): 2018.

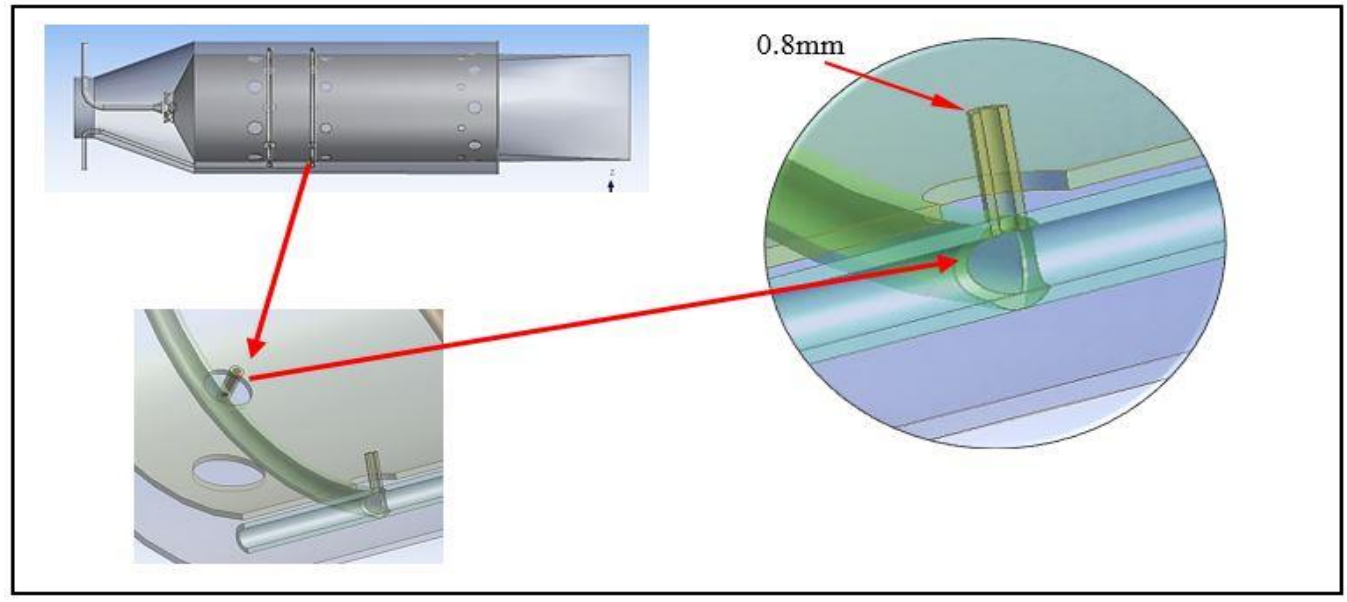

Figure: 2, Secondary line of fuel injection (S.L.F.I) details.

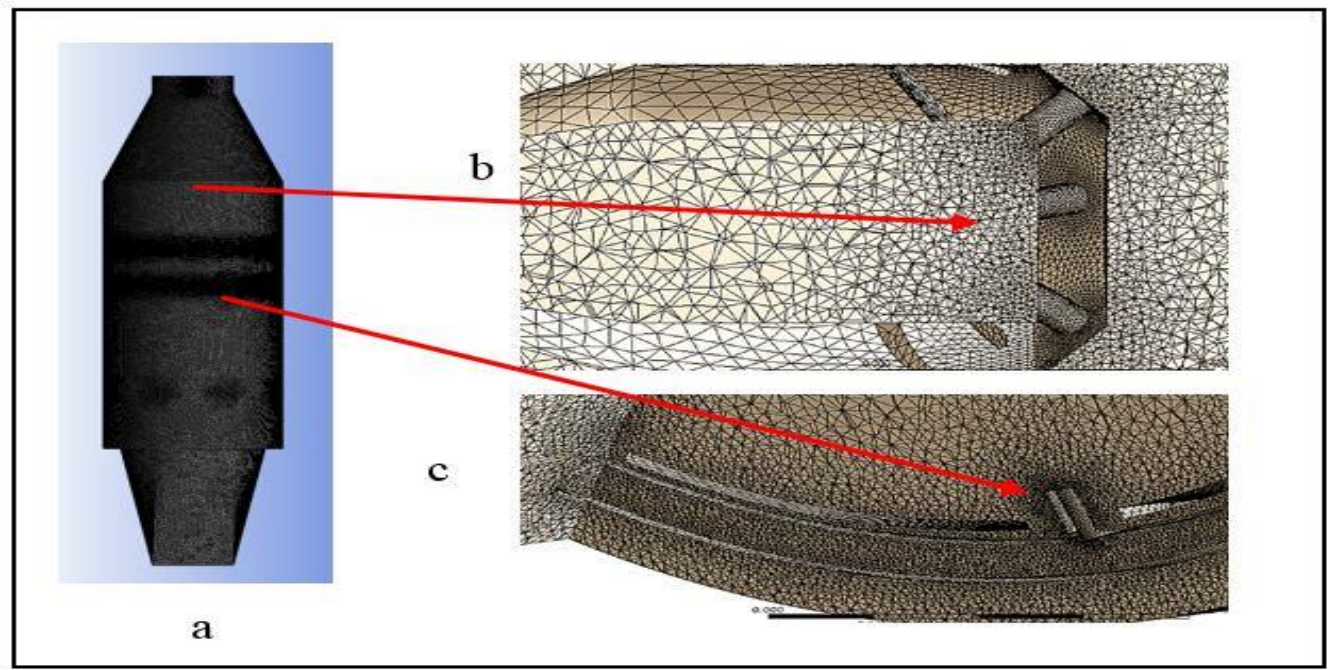

Figure: 3, Tetrahedral mesh distribution for the combustor, a- all domain, bmain injector domain, c- secondary injector domain

\section{Assumptions:}

Assumptions were proposed to simulate the combustion processes case as follows:

1. Steady-state condition.

2. Newtonian fluid.

3. Incompressible flow compressible fluid.

4. Three dimensional, Turbulent flow.

5. Body forces are neglected. 
Journal of University of Babylon for Engineering Sciences, Vol. (26), No. (7): 2018.

The Non-Premixed Combustion approach allows significant computational savings since the scalar combustion such as density; temperature and fraction of species become functions only. This allows the generation of a preliminary 3D look-up table for searching, during CFD calculation, as already mentioned, avoiding the need of calculating these scalar. The generation of the PDF table derived from the use of detailed kinetic mechanism for methane in a previous generation library flamelets. The master kinetic model, detailed, for the combustion of methane is derived from the Model Fuel Library maintained by Reaction Design For the global ARF about 170:1, 85:1, 56.6:1 varied mass fraction between two lines of fuel injection $F_{2} / F_{1}$ about $(0,0.333,1$ and 3$)$ as mass fraction also varied the inlet temperature (300, 400, 500 and $600 \mathrm{~K})$. Keeping the size of the primary and secondary holes area and position constant.

\section{Pattern factor calculation:}

Temperature profile at the exit section of the combustor defined as pattern factor represented the temperature homogeneity at the combustor outlet S. H. Chohen [2] and H. Lefebver [3] as follows:

Pattern factor $=\frac{T_{\max }-T_{4}}{T_{4}-T_{3}}$

\section{Results and Discussion:}

Numerical simulation were performed to obtained flow field to help develop an understanding of the flow field inside the combustor for different mass flow rate fraction of fuel injection configuration. The main goal of numerical was to predict the effect of the volumetric distribution of injected fuel on the emissions, temperature distribution profile inside the combustor and outlet temperature profile (pattern factor).

Temperature prediction illustrated in Figure: 4, shows variation of the temperature profile along the center line of the combustor, for $6 \mathrm{~g} / \mathrm{s}$ of fuel flow rate, with equivalence ration about 0.323 , results shows increasing in temperature uniformity as increasing of activation of the (S.L.F.I) at the expense of fuel flow rate in the main line of fuel injection, also the bulk temperature uniformity at $F_{2} / F_{1}$ about 1 to 3 , while Figure: 5 , shows the decreasing in pattern factor as increasing in $\mathrm{F}_{2} / \mathrm{F}_{1}$ because of

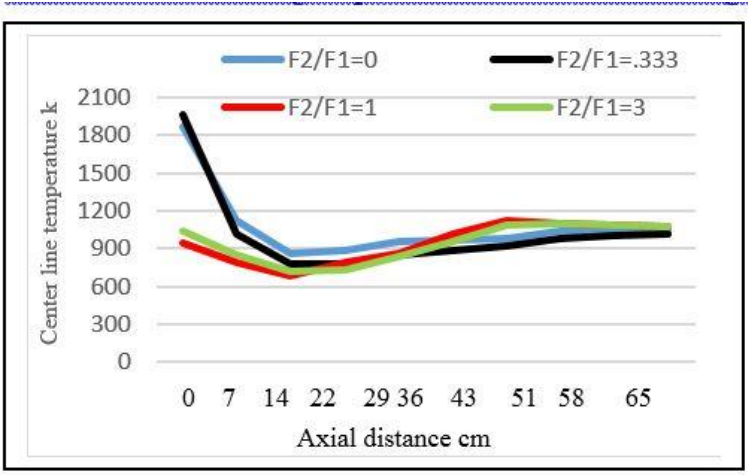

Figure: 4, Temperature profile along the center line of the combustor

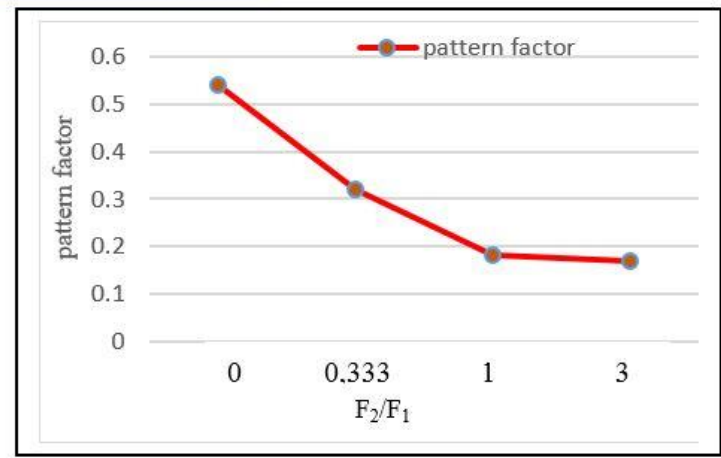

Figure: 5, Variation of pattern factor with mass F2/F1 
Journal of University of Babylon for Engineering Sciences, Vol. (26), No. (7): 2018.

Decreasing of hot spot and increasing in effectiveness of primary, secondary and dilution zone caused increasing in temperature homogeneity at combustor outlet.

Figure: 6, demonstrate the temperature contour inside the combustor for with difference fuel mass flow ratio on plane $\mathrm{a}$ and $\mathrm{b}$ the maximum temperature is formed near the fuel injection region. The temperature near the injector for all cases are observed to be higher than drop down stream (exhaust region) because the dilution effects of primary, secondary and dilution holes. However the hot spot reduce as increasing in activation of S.F.I.

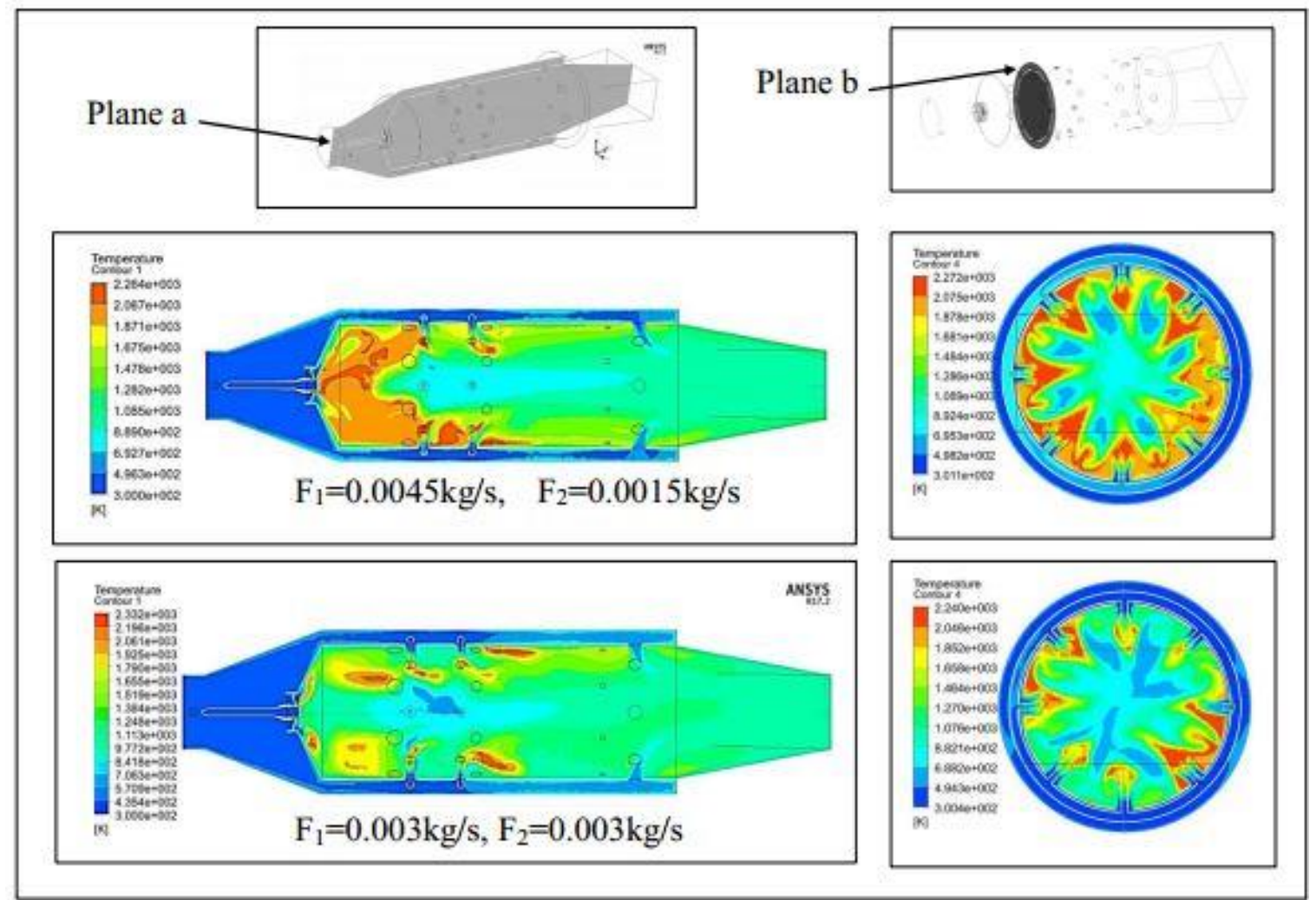

Fig: 6, contour plot of temperature distribution profile in plane a and $b$ for $F_{t} 0.006$

$\mathrm{kg} / \mathrm{s}, \Phi_{\text {total }}=0.303$ and inlet Air temperature T4=400k

Figures: 7, shows the mass fraction of $\mathrm{NO}$ concentration at the outlet section of the combustor results reveals that the NO concentration decrease as activation of secondary line of fuel injection due to decreasing in hot spot area where NO generation bounded with temperature 1700-2400K, H. Lephaver [3], figure: 8, shows the increasing in percentage of $\mathrm{NO}$ reduction with the increasing of activation of S.F.I line due to increasing in hot spot reduction with the increasing in $F_{2} / F_{1}$ for total fuel flow rate $\mathrm{F}_{\mathrm{t}}=0.004 \mathrm{~kg} / \mathrm{s}$ and $\Phi_{\text {total }}=0.202$. figure: 9 shows the difference in NO increasing for cases $F_{2} / F_{1}=0$ and $F_{2} / F_{1}=1$ with the increasing of equivalence ratio results shows increasing in difference of $\mathrm{NO}$ increasing as increasing in equivalence ratio due to increasing in $\mathrm{NO}$ generation for the case of $F_{1}=F_{t}$ i.e. activation of main line of fuel injection alone. 
Journal of University of Babylon for Engineering Sciences, Vol. (26), No. (7): 2018.

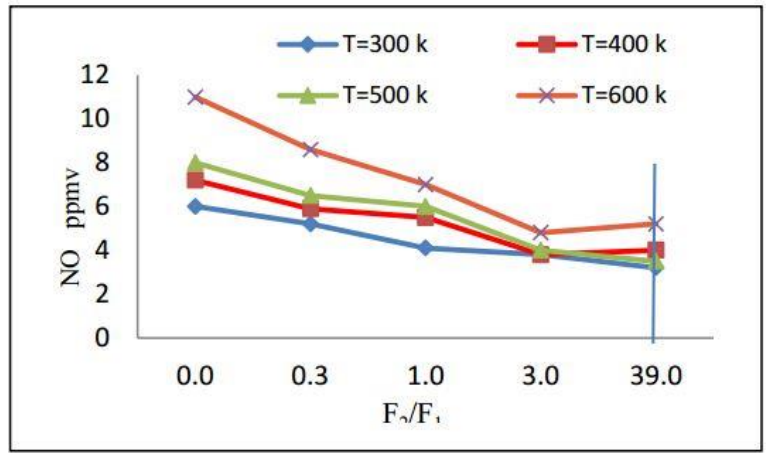

Figure: 7, Variation of NO concentration with fuel fraction and inlet air temperature, for $F_{t}=0.004 \mathrm{~kg} / \mathrm{s}$.

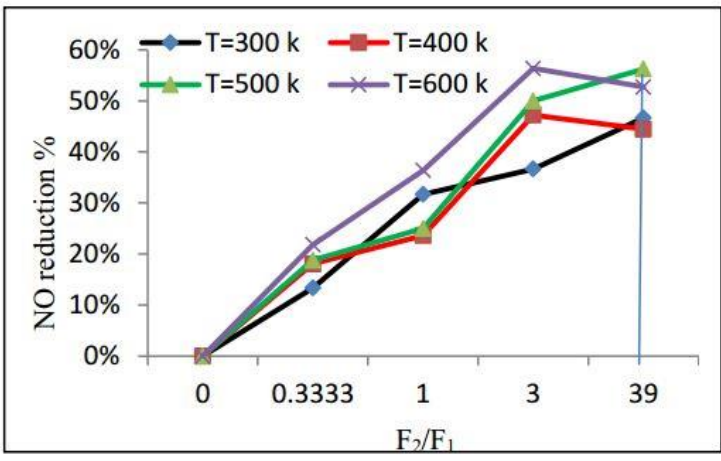

Figure: 8, percentage of the NO reduction with fuel injection mass fraction and Фtotal $=0.202, \mathrm{Ft}=0.004 \mathrm{~kg} / \mathrm{s}$.

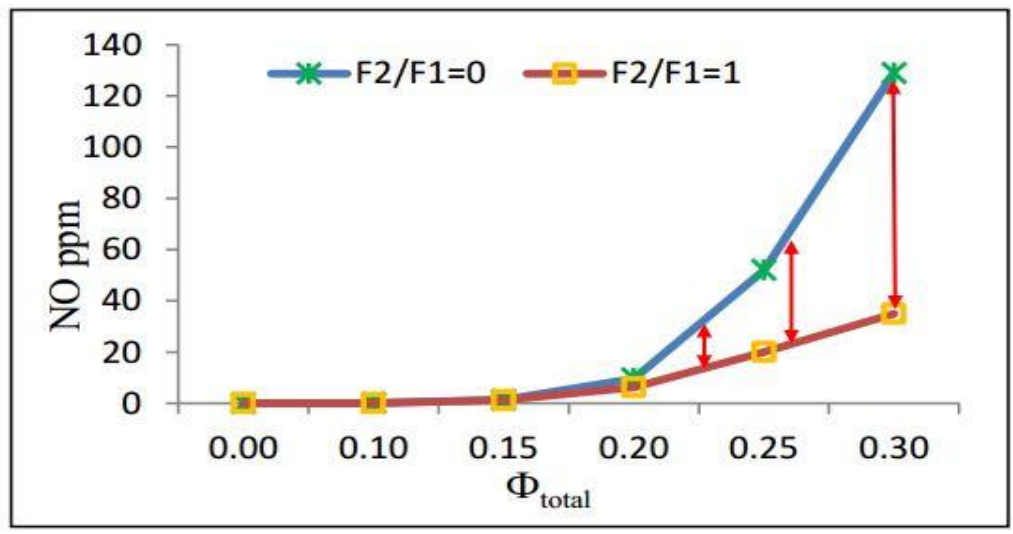

Figure: 9, Variation of NOx with the total equivalence ratio for temperature TAir $=400 \mathrm{~K}$

Figure. 10, a demonstrates the mass fraction of NO in volumetric rendering inside the combustor results reveals that the NO concentration decrease as activation of secondary line of fuel injection due to decreasing in generation of hot spot.

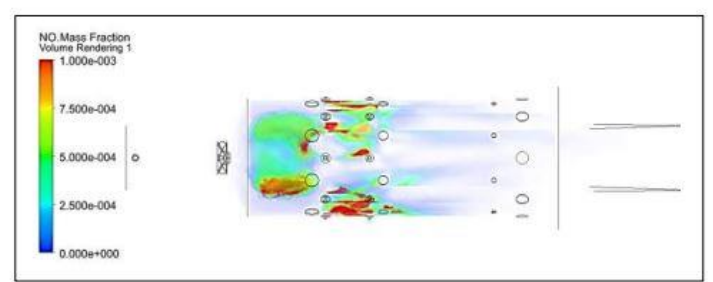

$\mathrm{F}_{2} / \mathrm{F}_{1}=0, \Phi_{\text {total }}=0.1$

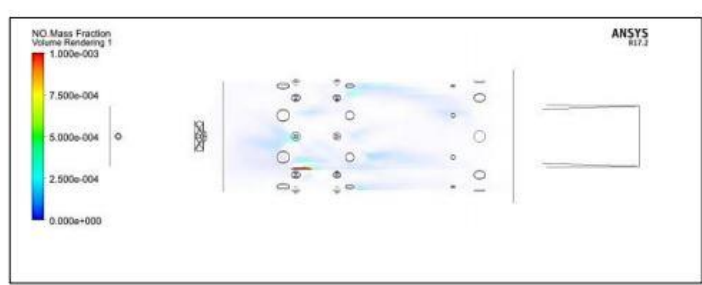

$\mathrm{F}_{2} / \mathrm{F}_{1}=1, \Phi_{\text {total }}=0.1$

Figure. 10. Volume rendering plot for the NOx emission for $F_{t} 0.002 \mathrm{~kg} / \mathrm{s}$ and air temperature $T_{\text {Air }}=400 \mathrm{~K}$. 
Journal of University of Babylon for Engineering Sciences, Vol. (26), No. (7): 2018.

Figure: 11, demonstrates the $\mathrm{O}_{2}$ mass fraction contours inside the combustor for cases $\mathrm{F}_{2} / \mathrm{F}_{1}=0$ and $\mathrm{F}_{2} / \mathrm{F}_{1}=1$ in plane $\mathrm{A}$. The $\mathrm{O}_{2}$ mass fraction is low in the primary region for $\mathrm{F}_{2} / \mathrm{F}_{1}=0$ while desirable condition accrues with increasing in activation of S.L.F.I. for $F_{2} / F_{1}=1$ by promote high oxygen concentration in all of the combustion chambers zones to preparing the reaction zone for complete combustion case by perfection of oxidizer distribution. Due to combustion process at that region and this in contrary $\mathrm{CO}_{2}$ contours as shown in Figure: 12.

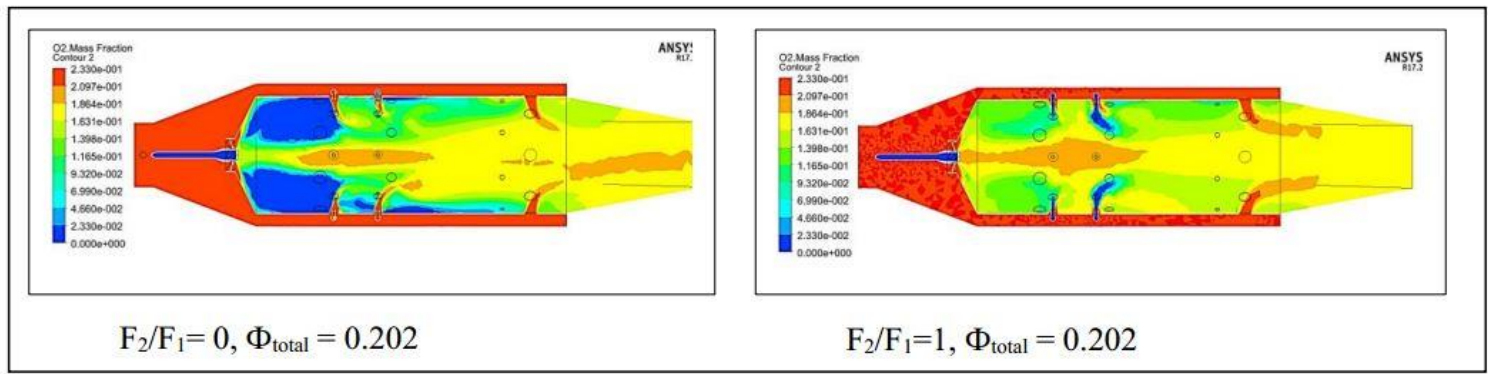

Figure: 11, contour plot of $\mathrm{O}_{2}$ concentration in axisymmetric plane $\mathrm{A}$ and Air temperature 400k

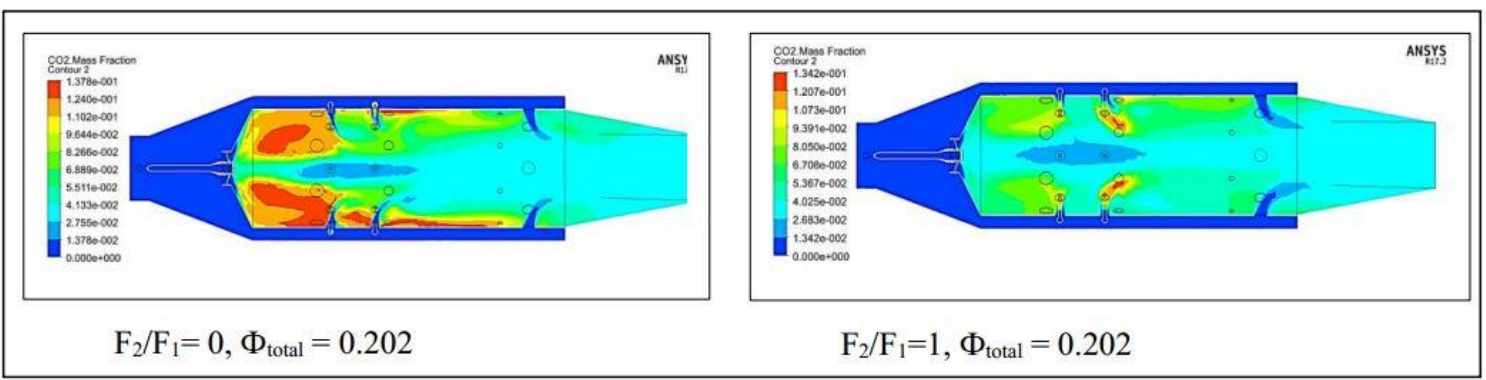

Figure: 12, contour plot of $\mathrm{CO} 2$ concentration in axisymmetric plane A and Air temperature $400 \mathrm{k}$

Figures: 13, demonstrates the axial velocity distribution profile inside the combustor for cases $6 \mathrm{~g} / \mathrm{s}$ fuel flow, results reveals increasing in accumulation of reverse flow region in recirculation zone and increasing in normal axial flow region as activation of secondary line of fuel injection due to the combustion effects on turbulence behavior by increasing the angler momentum with increasing of activation of S.L.F.I.

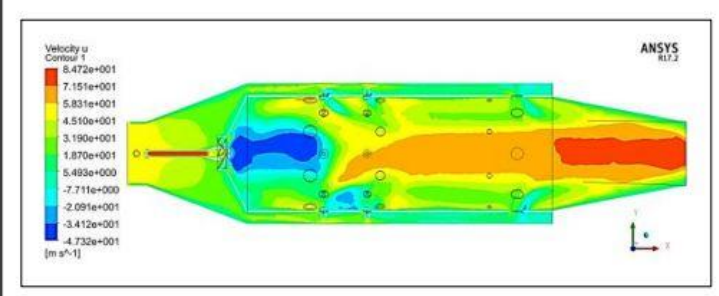

$\mathrm{F}_{2} / \mathrm{F}_{1}=0, \Phi_{\text {total }}=0.303$

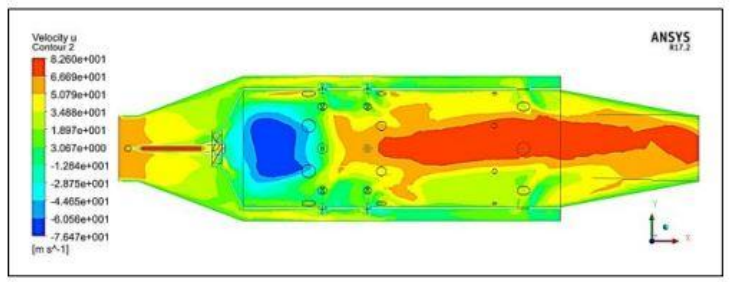

$\mathrm{F}_{2} / \mathrm{F}_{1}=1, \Phi_{\text {total }}=0.303$

Figure: 13, Predicted axial velocity profile counters at for $\Phi_{\text {total }}=\mathbf{0 . 3 0 3}$, inlet air temperature $\mathbf{T}_{\text {air }}=\mathbf{4 0 0} \mathrm{K}$. 
Journal of University of Babylon for Engineering Sciences, Vol. (26), No. (7): 2018.

\section{Conclusions:}

Low emission combustion enhancements using optimization of volumetric reaction phenomenon by using multi-port of fuel injection method is modeled in the combustor of a gas turbine using ANSYS, CFX 17.2 package for methane fuel with different inlet air temperature, equivalence ratio, and mass fraction of fuel injection line concluded.

1- Low emissions combustor achieved extremely low NO, when distributed flame was formed (distribution of hot spot).

2-High preheat temperature and high air flow rates helped in forming distributed flame (volumetric reaction), thus reducing the possibility to combustion instability.

3-The ultimate minimum low emission mode occurred only for a limited range of variation of mass fraction conditions for low equivalence ratio but with wide range for high equivalence ratio at fuel lean conditions.

4- Better performance for distributed fuel injection configuration the bulk fuel air mixing created in combustor caused hot spot reduction gives decreasing in NO concentration in about $30 \%$ to $56 \%$.

5- Distributed fuel injection promote perfection for oxidizer distribution in all zone of the combustion chamber caused god enhancement for complete reaction condition.

\section{Confllct of Interests.}

- There are no Conflicts of Interest.

\section{References.}

[1] J. W.Sawyer, "Gas Turbine Engineering Handbook,Theory and Design," Turbomach. Int. Publ. USA, 1985 pp. 5-1 to 5-62., vol. 1, p. 350, 1985.

[2] S. h.Cohen, G.F.C. Rogers, Gas Turbine Theory, Fourth ed. Longman Group Limited, Essex, England , 1996.

[3] H. Lefebvre and D. R. Ballal, Gas Turbine Combustion alternative fuel and Emissions, THIRD EDIT. Printed in the United States of America on acid-free paper $10987654321,1999$.

[4] G. B.Hornyák , Anita, "Numerical Modelling and Validation of the Combustion in a Gas Turbine,", 2012.

[5] F. Pathan , N. Patel, and M. Tadvi, "Numerical Investigation of the Combustion of Methane Air Mixture in Gas Turbine Can-Type Combustion Chamber," Ijser.Org, vol. 3, no. 10, pp. 1-7, 2012.

[6] F. Luis Goular Dias, M. Antonio Rosa do Nascimento, and L. de Oliveira Rodrigues "Reference Area Investigation in a Gas Turbine Combustion Chamber Using CFD," $J$. Mech. Eng. Autom., vol. 4, no. 2, pp. 73-82, 2014,. 
Journal of University of Babylon for Engineering Sciences, Vol. (26), No. (7): 2018.

[7] L.Wang , D. Qi, X. Sui, and X. Xie, "Analysis of Re Influence on MILD Combustion of Gas Turbine," Energy Power Eng., vol. 5, no. 20112, pp. 92-96, 2013.

[8] S. Kumaresh and M. Y. Kim, "Combustion and Emission Characteristics in a Cantype Combustion Chamber," vol. 8, no. 7, pp. 1304-1307, 2014.

[9] E. Oliveira, J. R. Barbosa, and W. P. Martignoni, "Influence of Air Intake Holes's Position for Primary and Secondary Zones on the Pattern Factor for Gas Turbine with Annular Combustors Designed for Ethanol," in International Conference Data Mining, Civil and Mechanical Engineering (ICDMCME'2014), Feb 4-5, 2014 Bali (Indonesia) , 2014. 
Journal of University of Babylon for Engineering Sciences, Vol. (26), No. (7): 2018.

\author{
اركان خلخال حسين \\ قسم الهندسة المبكانيكية جامعة التكنولوجيا، بغداد، العراق \\ arkanltaie@yahoo.com \\ محمود عطا الله مشكور \\ قسم الهندسة الميكانيكية جامعة التكنولوجيا، بغداد، العراق \\ Mahmood Mashkoor@ @ hot mail.com \\ فؤاد عبد الامير خلف \\ قسم العندسة المبكانيكية جامعة التكنولوجيا، بغداد، العراق \\ me.21325@uotechnology.edu.iq
}

الخلاصة

يقدم هذا العمل تقنيه لأعلى نمذجه لتصميم حارق أنبوبي لتوربين غازي، هذه التقنيه مبنيه على ديناميكية المائع الحسابي (CFD) بأستخدام برنامج (CFX) للتقليل من الأنبعاثات الغازيه بأستخدام حقن وقود متعدد المنافذ في الطوق الثانوي للحارق. يربط هذا البحث نسبة التدفق الكتلي لخطوط حقن الوقود ونسبه التكافؤ لخلط الوقود مع الأنبعاثات لحارق انبوبي مصمم لوقود الميثان. بأستخدام k-E للموديل الأضطر ابي و و PDF- Flamelet لموديل الأحتراق. تمثل الضروف التشغيليه المستخدمه بيانات لتوربين غازي صغير بأستخدام سريان خلط الوقود وتحليل الاحتراق مع التركيز على تركيز الانبعاثات في مقطع الخروج للحارق. مع تغير نسبة الوقود المحقون في خطوط

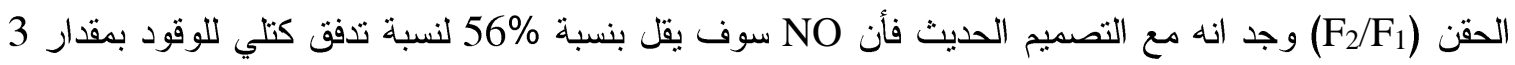
عندما تكون نسبه التكافؤ لخلط الوقود عاليه و 30\% لنسبة تدفق كتلي للوقود بمقدار 1 عندما تكون نسبه التكافؤ لخلط الوقود و اطئه، في حين هناك انخفاض في معامل نمط درجات الحراره في منطقة الخروج من 35\% ـ

الكلمات المفتاحية: - نوربين غازي، حارق انبوبي، انبعاثات و اطئه، وقود ميثان. 